\title{
AUTOCLAVE-ASSISTED DEACETYLATION: A RAPID METHOD TO RECYCLING CIGARETTE BUTTS INTO CELLULOSE
}

\author{
Putri Amanda ${ }^{1 *}$, Anisyah Putri², Nanang Masruchin ${ }^{1}$, \\ Wida Banar Kusumaningrum ${ }^{1}$, Riska Surya Ningrum ${ }^{1}$ and Ismadi ${ }^{1}$ \\ ${ }^{1}$ Research Center for Biomaterial, Indonesian Institute of Sciences, Cibinong Science Center, Jl. \\ Raya Bogor KM 46, Cibinong, 16911, Indonesia \\ ${ }^{2}$ Departement of Chemistry, Faculty of Mathematics and Natural Sciences, Universitas Gajah \\ Mada, Sekip Utara Bulaksumur, Yogyakarta, 55281, Indonesia \\ E-mail: putri.amanda@lipi.go.id
}

Received: 10 July 2020

Revised: 15 October $2020 \quad$ Accepted: 22 October 2020

\begin{abstract}
AUTOCLAVE-ASSISTED DEACETYLATION: A RAPID METHOD TO RECYCLING CIGARETTE BUTTS INTO CELLULOSE. Cellulose acetate (CA)-based materials, like cigarette butts (CBs), become one of the most com-mon types of litter in the world. The toxic substances that are contained make this waste carry a hazardous risk for the environment and living organisms. Herein we report a rapid method for recycling cigarettes butts into more environmen-tally material. Cellulose was fabricated by deacetylation of cigarette butts with $\mathrm{NaOH}$ solution at various times $15,30,45$, and 60 minutes in autoclave. Cellulose was optimized by a degree of deacetylation (DD\%) and was further charac-terized by FTIR, SEM, TGA, and DSC analysis. The DD\% and FTIR results confirmed the complete conversion of cellu-lose acetate from cigarette butts to cellulose within 15 minutes. Cellulose morphology under SEM showed the surface became rougher and textured after autoclave treatment. The results of autoclave-assisted deacetylation are comparable with the conventional deacetylation. Our rapid method offers substantially reduced deacetylation from 24 hours to just 15 minutes. This study has shown that the new and straightforward method for deacetylation cellulose acetate and it is potential as an alternative method for recycling cigarette butts waste in the future.
\end{abstract}

Keywords: Cigarette butts, Cellulose acetate, Cellulose, Deacetylation, Autoclave

\begin{abstract}
ABSTRAK
DEASETILASI DENGAN AUTOKLAF: METODA CEPAT UNTUK DAUR ULANG PUNTUNG ROKOK MENJADI SELULOSA. Material berbasis selulosa asetat (CA) seperti puntung rokok(CB), menjadi salah satu sampah yang paling umum di dunia. Zat beracun yang terkandung didalamnya membuat sampah ini membawa risiko berbahaya bagi lingkungan dan makhuk hidup. Pada penelitian ini kami melaporkan metode yang cepat untuk daur ulang puntung rokok menjadi matrerial yang lebih ramah lingkungan. Puntung rokok di konversi menjadi selulosa dengan cara deasetilasi menggunakan larutan $\mathrm{NaOH}$ dengan berbagai variasi waktu: 15, 30, 45, dan 60 menit menggunakan autoklaf. Konversi selulosa asetat di buktikan dengan perhitungan derajat deasetilasi (DD\%) dilanjutkan dengan analisis FTIR, SEM, TGA, dan DSC. Hasil DD\% dan FTIR mengkonfirmasi konversi lengkap selulosa asetat dari puntung menjadi selulosa dalam waktu 15 menit. Morfologi selulosa hasil konversi menggunakan autoklaf dengan SEM menunjukkan permukaan yang lebih kasar dan bertekstur. Selulosa yang diperoleh dari hasil deasetilasi menggunakan autoklaf sebanding dengan deasetilasi
\end{abstract}


secara konvensional. Metoda ini menawarkan proses deasetilasi yang lebih cepat yaitu berkurang dari 24 jam menjadi 15 menit. Penelitian ini menunjukkan penggunaan autoklaf dapat menjadi cara baru dalam deaasetilasi selulosa asetat dari puntung rokok dan berpotensi sebagai metoda alternatif untuk daur ulang sampah puntung rokok dimasa depan.

Kata kunci: Puntung rokok, Selulosa asetat, Deasetilasi, Autoklaf

\section{INTRODUCTION}

Cigarette butts (CBs), the common name for the remains of a cigarette after smoking, is one of the most common types of litter in the world [1]. These wastes are small but are saturated with toxic compounds. Approximately more than a thousand chemicals have been reported in CBs. These in-clude heavy metals, ethyl phenol, nicotine, carbon monoxide, hydrogen cyanide, nitrogen oxides, and other polycyclic aromatic hydrocarbons, which are known to be carcinogenic to humans[2]-[4]. These chemicals are released into the environment, de-pending on the conditions and chemical properties. Then, they contaminate soil and be leached by rainwater and brought to surface water and contaminate aquatic environments [2], [3]. The environ-mental impact of cigarette butts is related to its chemical composition. In consequence, the toxicity of cigarette butts was significantly influencing en-vironmental and public health areas [5], [6].

Although governments worldwide imple-ment legislation toward reducing cigarette con-sumption and reduce cigarette butts as sources of litter, there is an urgent need to recycle this haz-ardous pollutant [7]. Torkashvand \& Farzadkia, 2019 [8] reviewed various solutions for cigarette butt management. They present a critical review of the research available in the literature on the recy-cling of CBs as an inert component of other high-value-added materials. Bandi et.al (2018) [9] and Mohajerani et.al (2017) [10] Identified a recycling methodology for this kind of waste would reduce the release of dangerous materials into the envi-ronment and the ecosystem and encourage the re-cycling of resources.

Almost $90 \%$ of all cigarettes filters in the world are manufactured with cellulose acetate (CA) fibers except in Japan, Venezuela, South Ko-rea, and Hungary [10] and Glycerol triacetate as plasticizers are applied to bond the fibers [11]. Cel-lulose acetates are important esters of cellulose obtained from natural polymer with a wide range of properties [12]-[15]. Although CA can be pro-duced with a range of degrees of substitution (DS), the most common level of DS is 2.5 due to good solubility in common solvents, molecular weights, and melt properties [16]. Cigarette butts have a de-gree of substitution about 2.5; this high degree of acetylation makes CBs challenging to degrade. Re-search shows that cellulose acetate-based cigarette butts do not biodegrade under most circumstances because of their compressed makeup and the pres-ence of acetyl molecules [5], [7], [13]. For CA deg-radation, the DS must reduce from 2.5 to 1 . In the environment, DS reduction or deacetylation pro-ceed by hydrolysis, and CA hydrolysis is a slow process at ambient condition [17]. Several mecha-nisms are known such as chemical, enzymatic [13] photodegradation, and thermal degradation [18] for the deacetylation of CA. Regarding cigarette butts, the highly entangled network of the fibers mixed with plasticizers made the disintegration of butts very slow and challenging.

Deacetylation is one of the possible treatments of CBs to make them less harmful and to give the waste a second life through the production of sec-ondary raw materials or products that are already usable on the market. CA in CBs can be easily deacetylated and convert to cellulose by hydroly-sis. CA's deacetylation is usually performed through a hydrolysis method using alkoxide, acid-ic, or alkali solutions [19]-[21], either aqueous or alcoholic alkali solutions [22]

The degree of the deacetylation and the time to achieve the deacetylation depend on several fac-tors, including solvent type, alkali concentration and liquor to fiber ratio. Liu and Hsieh reported that reaction time was crucial for the deacetyla-tion results [22], Xuezhong He investigated the deacetylation CA and the result showed that the importance of the deacetylation parameters was sorted as Solution $>$ Swelling time $>$ Reaction time $>$ Concentration [23].

The reaction time has significant influences on the deacetylation results, and this is related to the swelling time of CA. Swelling time is fast, so the reaction time will be fast because the acetyl group is more easily 
in contact with an alkaline solution. Hence the deacetylation reaction occurs more quickly [23].

Ahmed et al (2017) [24] reported a rapid method for the deacetylation of CA nanofibers to produce cellulose nanofibers using external force known as ultrasonic energy. The energy makes CA's swelling faster than using the conventional method and this method offers substantially re-duced deacetylation time from 30 hours to just 1 hour.

In this research, we proposed a novel method to provide a fast and effective route to fabricate cellulose from CBs by hydrothermal method using an autoclave. From thermodynamics of polymer networks, it is known two opposing factors drive that degree of swelling: one involves the solvent-polymer interaction which results in changes in the mixing free energy of the system, and another factor is due to elastic forces within the polymeric network, caused by increasing water content with-in it [25]. Due to the analysis principle, which is different form previous establish method, the use of autoclave can speed up the reaction time and then speeding up the deacetylation process.

We use several characterizations such as qualitative testing, Fourier Transform Infrared spectroscopy (FTIR for cellulose chemical struc-tures, scanning electron microscope (SEM) to in-vestigate the change of morphology, and thermal analysis with TGA and DSC to confirm the suc-cessful of this method.

This method can be an alternative step in managing cigarette butts waste, and it is more suit-able for large scale production of cellulose from CBs.

\section{EXPERIMENTAL METHOD}

\section{Materials and Instruments}

Cigarette butts (CBs) were collected on Cibinong Science Centre - Botanical garden (CSC-BG) Cibinong, dimethylformamide (DMF, ACS reagent grade, SigmaAldrich), Ethanol ( $\mathrm{C}_{2} \mathrm{H}_{5} \mathrm{OH}, 99.8 \%$, Sigma-Aldrich), sodium hydroxide pellets $(\mathrm{NaOH}$, Sigma- Aldrich), sulfuric acid ( $\mathrm{H}_{2} \mathrm{SO} 4,98 \%$ Sigma-Aldrich), Sodium Chloride ( $\mathrm{NaCl}$, Sigma-Aldrich) and Sodium Hypochlorite solution with chlorine content $12 \%$ ( $\mathrm{NaClO}$, SigmaAldrich). All chemicals were used as received.

\section{Method and Procedure}

\section{Preparation of Cigarettes butts}

The filters were first manually separated from paper and tobacco. Filters (ca. $10 \mathrm{~g}$ ) were then soaked and washed with water, drained and extracted with ethanol $(20 \mathrm{~mL} / \mathrm{g})$ for $24 \mathrm{~h}$ at room temperature. After extraction, the obtained cellulose acetate was bleached using $5 \mathrm{w} / \mathrm{v} \% \mathrm{NaOCl}(10 \mathrm{~mL} / \mathrm{g})$ for $6 \mathrm{~h}$ at room temperature and then dried at room temperature for $72 \mathrm{~h}$ [7].

\section{Deacetylation of Cigarette Butts}

The obtained dried CBs was deacetylated using $0.25 \mathrm{M} \mathrm{NaOH}$ solution $(20 \mathrm{~mL} / \mathrm{g})$ in autoclave at the temperatures of $121^{\circ} \mathrm{C}$ with the variation of times; 60,45 , 30 and 15 minutes. For comparison, conventional deacetylation was also carried out using Ethanolic- $\mathrm{NaOH}$ (Cel-EtOH/ $\mathrm{NaOH})$ at room temperature for 24 hours. All the cellulose samples were thoroughly rinsed-off in distilled water until their $\mathrm{pH}$ reached to neutral. The percentage yield of the Cellulose was determined gravimetrically.

\section{Degree of Deacetylation (DD\%)}

The degree of deacetylation (DD\%) of CBs was measured using compare degree of substitution of acetyl CBs before and after deacetylation. Degree of substitution of acetyl $\left(\mathrm{DS}_{\text {acetyl }}\right)$ was measured using equation (1) [24].

$$
\begin{aligned}
& \text { Acetyl }(\%)=\left[(D-C) N a+(A-B) N b \times \frac{4.305}{W}\right. \\
& \mathrm{DS}_{\text {acetyl }}=\frac{\left\{162 \times \frac{\% \text { asetil }}{43}\right\}}{\left\{100-\left(\frac{42}{43} \times \% \text { Asetil }\right)\right\}} \times 100 \%
\end{aligned}
$$

Where, $\mathrm{W}$ is the sample weight, $\mathrm{A}$ and $\mathrm{B}$ are the volume $\mathrm{NaOH}$ solution to titration sample and blank, $\mathrm{C}$ and $\mathrm{D}$ are the volume $\mathrm{HCl}$ solution to titration sample and blank, and $\mathrm{Na}$ and $\mathrm{Nb}$ are concentration of $\mathrm{NaOH}$ and $\mathrm{HCl}$

\section{Characterizations}

The morphology of each sample was determined under the scanning electron microscope (SEM) by Hitachi SU-3500 with an accelerating voltage of $5.00 \mathrm{kV}$ and a maximum magnification of $5000 \times$ In order to confirm CBs to cellulose conversion, the Cellulose were examined using Fourier Transform Infrared spectroscopy (FTIR) Perkin Elmer Spectrum Two. All the nanofiber samples were analysed at ATR-FTIR mode. A qualitative test was also conducted for confirmation of $\mathrm{CB}$ to cellulose conversion, considering the solubility of $\mathrm{CB}$ 


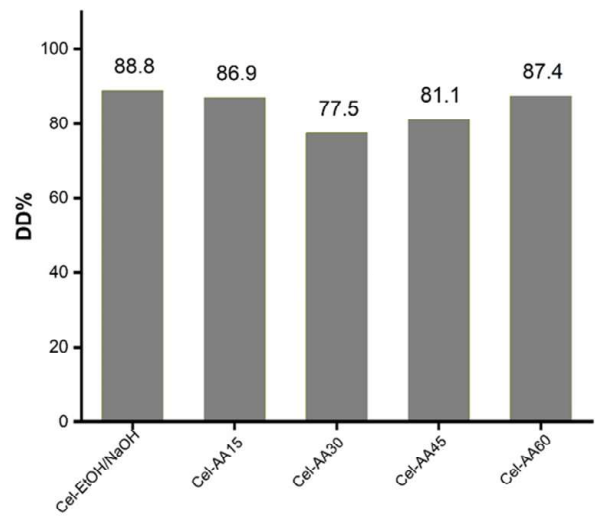

Figure 1. The DD\% of conventional deacetylated and Autoclave assisted deacetylated of cigarette butts.

and insolubility of Cellulose in DMF. The insolubility of the sample confirms $\mathrm{CB}$ to cellulose conversion since Cellulose is insoluble in the DMF. DSC and TGA were performed in order to determine the thermal properties of both samples. Thermogravimetric analysis (TGA) was carried out using Perkin Elmer 4000. The analyses were conducted using a sample mass in the range 4-5 $\mathrm{mg}$ in a nitrogen atmosphere (flow rate of $20 \mathrm{~mL} / \mathrm{min}$ ) with a constant heating rate of $10{ }^{\circ} \mathrm{C} / \mathrm{min}$ and at temperature of $25-500^{\circ} \mathrm{C}$. DSC analyses were performed using a PerkinElmer DSC 4000 with Pyris-1 analyser, at temperature of $25-320^{\circ} \mathrm{C}$

\section{RESULT AND DISCUSSION}

\section{Degree of Deacetylation (DD\%) of CBs}

Figure 1 shows the effect of different time (60, 45,30 and 15 minutes) and treatment (conventional and autoclave deacetylated) on $\mathrm{DD} \%$ during the autoclaved assisted deacetylation (AA-deacetylation) of CBs. It can be seen from Figure 1, In general, after deacetylation the $\mathrm{DD} \%$ of all results of deacetylation CBs resides at a range of $70-87 \%$. The autoclave treatment shows the
DD\% have similar values to the conventional deacetylation. This revealed that autoclaved treatment could be used in the deacetylated process of CBs.

\section{Qualitative assessment of Cellulose solubil- ity test}

Qualitative testing with DMF solution was the most straightforward way that we choose to see the success of conversion CBs into cellulose. Similar qualitative testing is also performed by Ahmed et al. 2017 [24] on deacetylated electrospinning of cellulose acetate. Cellulose has a strong hydrogen bond that makes insoluble in the organic solvent such as DMF [17]. However, DMF is a good solvent for CA because its solubility parameter is comparable to that of CA. The Hildebrand solubility parametersare $25.1 \mathrm{MPa}^{1 / 2}$ and 24.8 $\mathrm{MPa}^{1 / 2}$ for CA and DMF respectively [26]. All the deacetylation results of $\mathrm{CBs}$ were insoluble in DMF, proving the conversion to cellulose was successful. Furthermore, we found the interesting result that can be seen in Figure 1. The DD\% of AA-deacetylation process at 15 minutes and 60 minutes showed not significantly different; $86.9 \%$ and $87.4 \%$ respectively. This value does not differ considerably, compared to the time that is saved around if only do autoclave for 15 Minutes. So, 15 minutes of sample treatment in the autoclave was chosen for further investigation.

\section{Chemical Structure of Cellulose}

The FTIR spectra of CB, Cellulose from conventional deacetylation and autoclaved assisted deacetylation (Cel-EtOH/NaOH and Cel-AA) with variations of time are shown in Figure 2. The characteristic absorption peaks of cellulose acetate

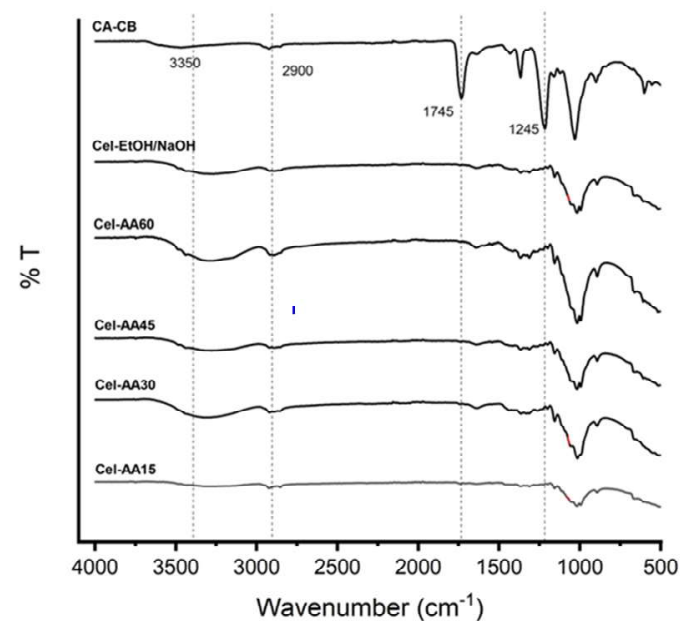

Figure 2. FTIR Spectra of CBs and deacetylated CBs. 

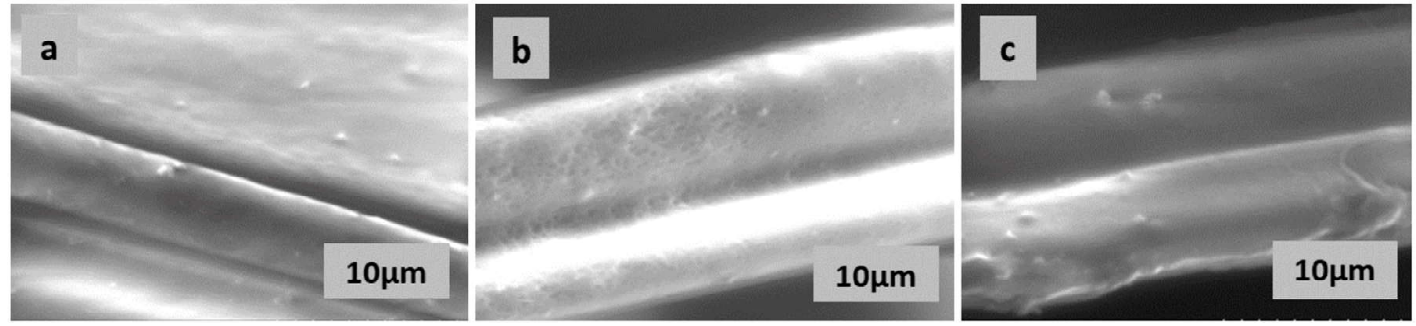

Figure 3. SEM images of (a) $\mathrm{CCB}$ (b) $\mathrm{Cel}-\mathrm{EtOH} / \mathrm{NaOH}$ (c) Cel-AA15.

attributed to the vibrations of carbonyl $(\mathrm{C}=\mathrm{O})$, stretching of ester $\mathrm{C}-\mathrm{H}$ in $\mathrm{O}-(\mathrm{C}=\mathrm{O})-\mathrm{CH}_{3}$ and stretching of acetyl groups at $1745 \mathrm{~cm}^{\prime \prime}, 1375 \mathrm{~cm}^{\prime \prime}$, and $1235 \mathrm{~cm}^{\prime \prime}$ are observed in the $\mathrm{CB}$, confirm that the cigarette butts were made of cellulose acetate. These characteristics peaks of CA disappeared in the deacetylated CBs by conventional and autoclave assisted deacetylation. Furthermore, the absorption peak at $3600-3300 \mathrm{~cm}^{\prime 1}$ attributed to O-H groups detected in both samples. FTIR Spectra for $\mathrm{CB}$ indicate broad spectrum centering around 3600-3500 $\mathrm{cm}^{-1}$ and with progressive aqueous hydrolysis, the hydroxyl peak broadens and shifts to lower wavenumbers $3350 \mathrm{~cm}^{-1}$, suggesting the formation of hydrogen bonding. The disappearance CA peaks and the emergence of new -OH peaks in all deacetylated $\mathrm{CBs}$ confirm that the $\mathrm{CB}$ has been converted into cellulose. It also showed in Fig. 2. that the FTIR spectra of Cel-AA deacetylation showed similar spectra to the Cel-EtOH/ $\mathrm{NaOH}$. It is shown that the characteristic bands of cellulose remain unchanged after autoclave assisted deacetylation; this determines that autoclave assisted has no negative effect on the chemical structure of cellulose.

\section{Effect of autoclave-assisted deacetylation on cellulose morphology}

To study the effect of autoclave-assisted deacetylation on cellulose's morphology, the samples; $\mathrm{CBs}$, Cel-AA15 and Cel-EtOH/NaOH were analyzed by Scanning Electron Microscopy (SEM) technique. Figure 3 (a) - (c) shows the surface morphology of CB, conventional deacetylated $\mathrm{CBs}$, and Autoclave-assisted deacetylation CBs. After deacetylation assisted by autoclave, CBs became rougher and textured (Fig. 3c). The rough cellulose surface is because in hydrothermal processes such as the autoclave, the sample is exposed to pressure and heat resulting in substantial break down of the cellulose structure.

\section{Thermal Analysis of Cellulose}

TGA and DSC thermograms were employed to investigates the thermal behavior of CBs and Cel-AA15. TGA thermograms in Figure 4. showed that both samples have similar thermal degradation mechanisms but different in degradation rate. TGA results showed two main thermal steps in CBs: desorption of water adsorbed and evaporation of volatile compounds (between $30^{\circ} \mathrm{C}$ and $200^{\circ} \mathrm{C}$ ) and pyrolytic decomposition of CA polymer chain skeleton followed by between $200^{\circ} \mathrm{C}$ and $400^{\circ} \mathrm{C}$ with maximum degradation at $385^{\circ} \mathrm{C}$ with weight loss about $67 \%$. \%. Desorption water of $\mathrm{CBs}$ represented only $3.7 \%$ of the total loss of mass in the TGA analysis.

In Cel-AA15, desorption water is $7.4 \%$ of the total loss of mass. This result higher than the CB loss mass. It is because the deacetylation reaction made the amount of hydroxyl group in cellulose increase. The maximum degradation occurs at a temperature of $335^{\circ} \mathrm{C}$ with a weight loss of $53 \%$. This value is not much different as Ogundare et al. reported in 2017, where cellulose from cigarette butts had a maximum degradation temperature at $320^{\circ} \mathrm{C}$. Figure 4 only shows the thermogram of cellulose from conventional deacetylation (Cel-EtOH/NaOH). It can be seen that Cel-AA15 showed similar thermal characteristics with $\mathrm{Cel}-\mathrm{EtOH} / \mathrm{NaOH}$, which proves that the autoclave assisted in deacetylation process does not damage the chemical structure as evidenced by similar thermal properties both of sample.

The maximum degradation temperature of $\mathrm{CBs}$ is higher than the maximum degradation temperature of CelAA15, indicated that cellulose has low thermal degradation. However, cellulose has higher thermal resistance, evidenced by lower degradation rate so that the percentage of cellulose end weight is higher than that of cellulose acetate cigarette butts.

The thermal properties of cellulose from deacetylated cigarette butts can also be seen from the DSC measurement results. In Figure 5. the thermogram DSC of CBs is shown the melting point at $220{ }^{\circ} \mathrm{C}$ as an indication of the occurrence of phase transitions. 


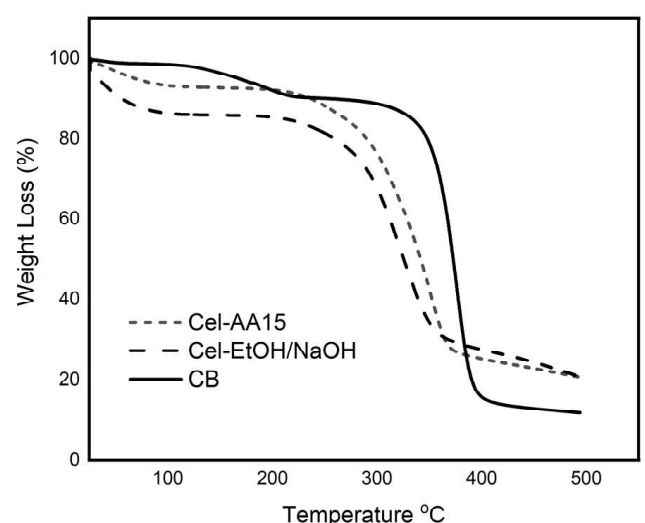

Figure 4. Thermogravimetric analysis (TGA) thermograms of $\mathrm{CB}, \mathrm{Cel}-\mathrm{EtOH} / \mathrm{NaOH}$ and Cell-AA15.

On the contrary, the CBs after being AAdeacetylation did not show any fusion peaks or phase transitions due to its amorphous characteristics, in addition these thermogram have similar characteristic with DSC thermogram of Cel-EtOH/NaOH. This proves that autoclaved assisted deacetylation successfully converts $\mathrm{CBs}$ into cellulose.

\section{CONCLUSION}

Recycling of Cigarette butts have been successfully carried out through deacetylated reaction with $\mathrm{NaOH}$ solution assisted by autoclave. Deacetylated assisted by autoclave for 15 minutes can already remove $87 \%$ of the acetyl group. FTIR results showed the removal of acetyl groups and the appearance of $-\mathrm{OH}$ groups after autoclaved $\neg$ assisted deacetylation confirms that the conversion of cellulose acetate from cigarette butts into cellulose. Surface morphology of regenerated cellulose under SEM showed the surface became rougher and textured in the case of autoclaved assisted deacetylation. We concluded that the 24 hours treatment time of conventional deacetylation substantially reduced to 15 minutes with autoclaved during the deacetylation. Our new method offers a rapid treatment for cellulose acetate conversion into cellulose, thereby ensuring a new method for recycling cigarette butt waste. These results can be of great interest to territories around the world. They can inspire the application of waste disposal solutions and technologies that have a substantial environmental impact and help develop other products according to the circular economy paradigm.

\section{ACKNOWLEDGEMENT}

The authors acknowledge the facilities, and the scientific and technical assistance of the Integrated

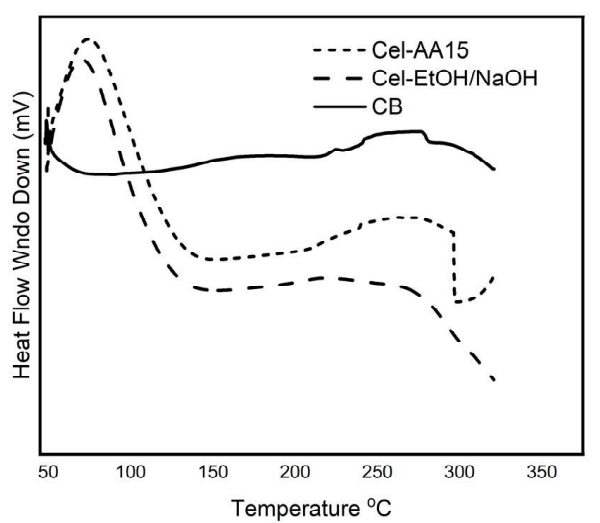

Figure 5. The DSC thermograms of $\mathrm{CB}, \mathrm{Cel}-\mathrm{EtOH} / \mathrm{NaOH}$ and Cell-AA15.

Laboratory of Bioproducts at the Indonesian Institute of Science".

\section{REFERENCES}

[1] WHO, Tobacco and its environmental impact: an overview. WHO: Geneva, 2017.

[2] F. X. Joly and M. Coulis. "Comparison of cellulose vs. plastic cigarette filter decomposition under distinct disposal environments." Waste Management, vol. 72, pp. 349-353, 2018.

[3] E. Abu-Danso, A. Bagheri, and A. Bhatnagar. "Facile functionalization of cellulose from discarded cigarette butts for the removal of diclofenac from water." Carbohydrate Polymer, vol. 219, pp. 46-55, 2019.

[4] E. Slaughter, R. M. Gersberg, K. Watanabe, J. Rudolph, C. Stransky, and T. E. Novotny. "Toxicity of cigarette butts, and their chemical components, to marine and freshwater fish." Tobacco Control, vol. 20, no. 1 SUPPL, pp. 25-29, 2011.

[5] M. J. Benavente, M. J. A. Caballero, G. Silvero, I. López-Coca, and V. G. Escobar. "Cellulose Acetate Recovery from Cigarette Butts." Proceedings, vol. 2, no. 20, p. 1447, 2019.

[6] T. E. Novotny and E. Slaughter. "Tobacco Product Waste/ : An Environmental Approach to Reduce Tobacco Tobacco Product Waste: An Environmental Approach to Reduce Tobacco Consumption." Current Environmental Health Reports, vol. 1, no. 3, pp. 208-216, May 2014.

[7] S. A. Ogundare, V. Moodley, and W. E. van Zyl. "Nanocrystalline cellulose isolated from discarded cigarette filters." Carbohydrate Polymer, vol. 175, pp. 273-281, 2017.

[8] J. Torkashvand and M. Farzadkia. "A systematic 
review on cigarette butt management as a hazardous waste and prevalent litter: control and recycling." Environmental Science and Pollution Research, vol. 26, pp. 11618-11639, Apr. 2019.

[9] R. Bandi, N. P. Devulapalli, R. Dadigala, B. R. Gangapuram, and V. Guttena. "Facile Conversion of Toxic Cigarette Butts to N,S-Codoped Carbon Dots and Their Application in Fluorescent Film, Security Ink, Bioimaging, Sensing and Logic Gate Operation.” ACS Omega, vol. 3, no. 10, pp. 13454 13466, 2018.

[10] A. Mohajerani, Y. Tanriverdi, B.T. Nguyen, K.K Wong, H.N. Dissanayake, L. Johnson, D. Whitfield, G. Thomson, E. Alqattan, A. Rezaei. "Physicomechanical properties of asphalt concrete incorporated with encapsulated cigarette butts." Construction and Building Materials, vol. 153, pp. 69-80, 2017.

[11] Y. Hamzah and L. Umar. "Preparation of creating active carbon from cigarette filter waste using microwave-induced $\mathrm{KOH}$ activation." Journal of Physics: Conference Series, vol. 853, no. 1, 2017.

[12] M. B. d'Heni Teixeira, M. A. B. Duarte, L. Raposo Garcez, J. Camargo Rubim, T. Hofmann Gatti, and P. A. Z. Suarez. "Process development for cigarette butts recycling into cellulose pulp." Waste Management, vol. 60, pp. 140-150, 2017.

[13] O. Haske-Cornelius et al. " Enzymatic systems for cellulose acetate degradation." Catalysts, vol. 7, no. 10,pp. 1-15, 2017.

[14] K. Rovina, S. Siddiquee, and N. K. Wong. "Development of melamine sensor based on ionic liquid/nanoparticles/chitosan with modified gold electrode for determination of melamine in milk product." Sensing and Bio-Sensing Research, vol. 4,pp. 16-22, 2015.

[15] E. Ernawati and M. Suhartini. "Sintesis Membran Kopolimerisasi Selulosa Asetat-Glutaraldehid Menggunakan Iradiasi Berkas Elektron untuk Pervaporasi Etanol-Air." Jurnal Sains Materi Indonesia, vol. 17, no. 2, pp. 56-62, 2016.

[16] J. Puls, S. A. Wilson, and D. Hölter. "Degradation of Cellulose Acetate-Based Materials: A Review." Journal of Polymers and the Environment, vol. 19, no. 1,pp. 152-165, 2011.

[17] R. M. Robertson, W. C. Thomas, N. Suthar, and D.
M. Brown. "Accelerated degradation of cellulose acetate cigarette filters using controlled- release acid catalysis.” Green Chemistry, vol. 14, pp. 22662272, 2012.

[18] M. Conceic, C. Lucena, A. E. V. De Alencar, S. E. Mazzeto, and S. D. A. Soares. "The effect of additives on the thermal degradation of cellulose acetate." Polymer Degradation and Stability, vol. 80, pp. 149-155, 2003.

[19] K. Kalwar and M. Shen. "Electrospun cellulose acetate nanofibers and Au@AgNPs for antimicrobial activity-A mini review." Nanotechnology Reviews, vol. 8, no. 1, pp. 246257,2019.

[20] M. Il Kim and Y. S. Lee. "Deacetylation of cellulose acetate nanofibers by fluorination for carbon nanofibers." Materials Letters, vol. 181, pp. 236239, 2016.

[21] N. Tulos, D. Harbottle, A. Hebden, P. Goswami, and R. S. Blackburn. "Kinetic Analysis of Cellulose Acetate/Cellulose II Hybrid Fiber Formation by Alkaline Hydrolysis." ACS Omega, vol. 4, no. 3, pp. 4936-4942, 2019.

[22] H. Liu and Y. Lo Hsieh. "Ultrafine fibrous cellulose membranes from electrospinning of cellulose acetate." Journal of Polymer Science Part B: Polymer Physics, vol. 40, no. 18, pp. 2119-2129, 2002.

[23] X. He. "Optimization of Deacetylation Process for Regenerated Cellulose Hollow Fiber Membranes." International Journal of Polymer Science, vol. 2017,2017.

[24] F. Ahmed et al.. "Ultrasonic-assisted deacetylation of cellulose acetate nanofibers: A rapid method to produce cellulose nanofibers." Ultrasonics Sonochemistry, vol. 36, pp. 319-325, 2017.

[25] V. A. Oliveira, V. Tacia C, and L. Versiane A. "Hydrogels of cellulose acetate crosslinked with pyromellitic dianhydride/ : Part I/ : Synthesis and swelling kinetics." Química Nova, vol. 36, no. 1, pp. 102-106, Dec. 2012.

[26] H. Lee, M. Nishino, D. Sohn, J. S. Lee, and I. S. Kim. "Control of the morphology of cellulose acetate nanofibers via electrospinning." Cellulose, vol. 25, no. 5, pp. 2829-2837, 2018. 